\title{
The Educational Effectiveness of Didactical Games in Project-based Science Learning among 5 th Grade Students
}

\author{
Muhamad Hugerat ${ }^{1 *}$, Naji Kortam ${ }^{1}$, Nassrin Toubia Maroun ${ }^{1}$, Ahmad Basheer ${ }^{1}$ \\ ${ }^{1}$ The Academic Arab College for Education in Israel - Haifa, ISRAEL
}

Received 8 April $2020 \cdot$ Accepted 18 August 2020

\begin{abstract}
The purpose of this study was to examine how the use of didactic games in teaching science affects the learning environment, achievement, and motivation among primary school students. The research population consisted of $1885^{\text {th }}$ grade students from two primary schools. This group was divided into an experimental group and a control group. The research tools consisted of two questionnaires: one to determine the motivation to study science, and the other to determine the learning environment. Moreover, a pre-test in science was administered before the intervention and a post-test was administered afterwards. In addition, 20 pupils were interviewed. It was found that the use of didactic games in teaching significantly increases student motivation to learn science and that it has a positive effect on all the components of the "learning environment", as perceived by the students. In classes in which didactic games were used, the classroom atmosphere improved more than in classes where such games were not used.
\end{abstract}

Keywords: didactic game, achievement, motivation, learning environment

\section{INTRODUCTION}

Recently there has been a renewed interest in the development and use of pedagogical games, since they provide an interesting approach to the appropriation of knowledge in the context of active learning (Triboni \& Weber, 2018). According to Hartley et al. (2013), Aristotle defined play as pleasure in doing something that has no continuation. Researchers agree that play is an activity that is carried out for its own sake, willingly and enjoyably, and not for any material gain. In other words, it is an "activity freely performed" (Tal, 1993). Krasnor \& Pepler (1980) stressed the main characteristics of play: flexibility, having positive effects, and driven by intrinsic motivation.

According to Mayo (2010), the main characteristics of educational games are as follows: Competition for personal achievement; the player achieves his goal and cooperates with a team that operates according to predetermined rules. Planning and strategy: The childplayer can develop or adopt a plan, a strategy, and tactics that contribute to the development of logical process thinking and creativity (Santini et al., 2018). Abiding by a system of accepted rules: The player learns to obey rules; this is something that can be useful in everyday situations in or outside the classroom, depending on whether it is in the context of a game (Begoray \& Stinner, 2005; Beswick, 2011). Free choice of steps: Games can be used to teach children how to make decisions and how to plan their next steps. They can also be used with adults, for example, regarding which activities are needed in their daily lives. A game provides possibilities for broad experiences, with no need to fear the consequences. When a game ends, the activity ceases; the next game can begin immediately or when it is convenient. This is why games are so pleasurable for both children and adults.

The aim of didactic games is to make scientific concepts easier for students to comprehend. A teaching method that includes the use of illustrative didactic games is optimal and efficient (Foster, 2008; McNeil \& Jarvin, 2007; Santini et al., 2018; Bailey \& Watson, 1998).

According to Shonkoff \& Levitt (2010), games contribute to the development of the imagination, inventiveness, creativity, learning habits, inquisitiveness, and a critical faculty, in addition to the acquisition and creation of new knowledge. Games are also very important at a more advanced age, because 


\section{Contribution to the literature}

- $\quad$ This article discusses classroom climate through didactic games in science teaching.

- This study will definitely interest students, improve the concentration of students in the teaching process, and improve the level of knowledge.

- This study can help science teachers plan their lessons, because finding show that students in the intervention group, who were exposed to educational games during traditional instruction exhibited significantly higher motivation and academic achievements, and better perceptions of their science learning environments than students in the control group who were exposed to only traditional instruction without educational games.

- This study showed that didactic games provide a way for enjoyable learning, development of curiosity and imagination, and development of social skills and abilities.

after childhood fewer neural connections are formed and neural networks will function more effectively the more they are used. Thus, for example, games that involve gross or fine motor skills increase the brain's neural flexibility and create more effective neural networks (Karbach \& Schubert, 2013).

Ben-Menahem (2005) opined that teachers should pay particular attention to the development of emotional intelligence in the classroom and should develop students' ability to mobilize energy for learning. He quoted physics Nobel Prize winner Richard Feynman, who said: "Why do I enjoy physics? I play with it. I do whatever I want. I don't do things because it's important for the development of nuclear physics; I do what is interesting and fun for me to play with". This quote shows that Feynman would not have made real contact with the process of discovery had he not developed drive, curiosity, interest, and enjoyment, which are emotional components (Ben-Menahem, 2005).

Several studies have shown that using games in teaching improves academic achievements in mathematics and the sciences (Kats, 2007; Randler \& Bogner, 2009). The symbolic and concrete representations of scientific concepts and processes that are expressed in didactic games induce the learned concepts to be observed and abstracted by the students.

Arbel et al. (2011) noted that the use of games in learning contributes to students' as well as teachers' motivation, enjoyment, and interest. Teaching and learning with the help of games is efficient because it makes natural learning possible and enables academic goals to be achieved indirectly.

According to Tal (1993), pure enjoyment should be an important goal of games that are part of the teaching process; he stressed that pleasure as well as intrinsic motivation contributes significantly to learning. A student whose motivation stems from an external source will be willing to make less of an effort to learn than a student who is internally motivated to learn. The internally motivated student will accept tasks that are more challenging and will be more highly motivated (Ames, 1992). In comparing the traditional assessment model and the game-based model, Sánchez-Rivas et al.
(2019) found that the "gamified" exam presented notable advantages associated with increased motivation and increased capacity of the assessment activity to continue the learning process beyond the school context.

In addition to the students' personal traits and the influence of the domain of knowledge, their learning environment is also very important (Santini et al., 2018; Siraj-Blatchford \& Kwi-Ok, 2014). Game-based learning enables an optimal learning environment for students (Jancic \& Hus, 2018). da Silva et al. (2018) found that students' opinions regarding games are largely positive, and that they consider games to be a complementary innovative didactic tool.

Moreno et al. (2014) created a didactic game (cheminoes) that enables the meaningful learning of some relationships between concepts such as chemical elements, valence, atomic number, and chemical symbol for the first 36 chemical elements of the periodic system. Those students who had played the game opined that the activity was positive and they considered the game to be an enjoyable way of interacting with the concepts. The learning environment generally consists of the student's social and cultural milieu, including his community and his school (Fraser \& Walberg, 1991). In a narrower sense, the environment consists of the classroom where the learning tasks are given and where the other participants in the process, namely, the students, are present. The learning environment's features and facilities can affect the way a student chooses objectives and forms his regulatory learning processes. The environment directs students towards certain aims that have a significant effect on their chosen objectives and on the way in which they operate in order to carry out their tasks (Hugerat, 2016).

In other words, different environments have a different effect on the way that students link their objectives to their strategies of action, and on the way they regulate their learning tasks (McCaslin \& Good, 1996). For example, classroom work that fosters competition may cause some students to be concerned about their academic abilities, and it will make it difficult for them to focus on their learning objectives. On the other hand, working in small groups, which by nature, 
is less formal and provides more choices, will encourage specific goals and will positively affect students' skills and abilities (Meece et al., 1988). Personal factors also affect students' achievement goals. These include, for example, previous learning experiences, family background, perception of one's abilities, and attitudes towards the subject. Interestingly, it was found that students with a high perception of their personal abilities tend to adopt specific goals, irrespective of their actual achievements (Pintrich, 2002). One study (Afari et al., 2013) showed that mathematical games can improve students' attitudes towards mathematics. Thus, teachers who introduce games and other pedagogical elements into their lessons can play a key role in improving the classroom environment and students' attitudes towards mathematics (Fraser \& Walberg, 1991). Liu and Chen (2013), in their study conducted with primary school students, investigated students' performance in learning science-related concepts using a card game. They found that the game was effective and increased students' academic success and their knowledge retention.

Sousa Lima et al. (2019) revealed that students who used the game as a complementary tool had higher performance in tests, compared with those who studied by only conventional learning methods. The use of didactic games in teaching contributes to students' personal development and social skills in various domains: Emotionally: Development of inner-personal communication and empathy (Schiller 2010), giving rise to greater intrinsic motivation and enjoyment, which contribute to successful learning outcomes. Socially: Development of interpersonal communication and empathy, in order to achieve an equilibrium between the individual and the group and to develop teamwork, which constitutes the foundation for $21^{\text {st }}$-century skills, and strengthens social intelligence (Goleman, 2006). Motor skills: Use of fine and gross motor skills, both of which are important for creating neural networks in the brain and for improving motor coordination (Karbach \& Schubert, 2013). Language: In addition to improving dialogue, language, and music, which occasionally accompany games, language and music are also important for shaping the architecture of the brain's neural pathways (Leisman et al., 2013). Cognition: Games contribute to acquiring knowledge and to creating new knowledge, to developing imagination, creativity, inventiveness, inquisitiveness, and the critical faculty, and to acquiring learning habits (Shonkoff \& Levitt, 2010). Health: Games in general, and especially games in which gross motor skills are utilized, significantly contribute to improving mood, reducing depression and anxiety symptoms, and reducing the risk of heart disease, stroke, and diabetes (Bassuk et al., 2013).

Triboni \& Weber (2018) argued that most didactic games fail to completely implement a cycle of reflection and action, thereby fostering mostly lower-order thinking skills and memorization, as opposed to critical thinking and problem-solving skills.

Classroom climate and motivation play a major role in the teaching-learning process. "Problem-Based Learning" (PBL)-Jigsaw Discussion (JD) (PBL-JD) is a student-centered teaching methodology applied in science education; it ensures that the students are actively involved throughout the learning process. PBL, which uses a jigsaw discussion (PBL-JD), is a highly immersive student-centered approach that allows students to extend their time, often over the entire semester, to investigate an authentic problem or issue while developing knowledge and skills. The project culminates in students sharing their information with a "real-world" audience, for example, through a final presentation, video, or report. By using this studentcentered approach, each student studies the topic materials. Then, students work in groups to share ideas, debate different viewpoints, and teach each other (Chang, 2009; Choe \& Drennan, 2001).

Jigsaw Discussion (JD) is a method that emphasizes peer learning by dividing the learning task among small groups of students. The jigsaw group arrangement allows students to help each other understand information about corresponding topics by apportioning the work to be learned - each student in a small group is responsible for acquiring expertise about a different topic, theory, or reading assignment, for example, and for sharing their expertise with others in the group. The jigsaw activity is organized by dividing a class into several groups and assigning each group a different, but linked topic (Chang, 2009; Saputra et al., 2019).

The main aim of this research was to examine the effect of the PBL-JD method on students' motivation to learn science, using educational didactic games, and on the science classroom climate among $5^{\text {th }}$ grade students. The research contribution focuses on the connection between teaching, by incorporating didactic games into science learning in terms of motivational achievement, and the learning environment for elementary school students.

\section{Research Question}

How and to what extent will the use of educational didactic games, using $P B l-J D$, affect fifth grade students' learning environment, motivation, and achievements?

\section{METHODOLOGY}

\section{Research Population}

The research population consisted of 188 fifth grade students from two primary schools. The experimental group consisted of four classes, two from each school, totaling 92 students, whereas the control group, also consisting of four classes, two from each school, totaled 96 students. Two qualified science teachers, one with 17 
years of teaching experience and the other with 26 years of experience, taught the four classes, two from each school.

It was very important to us as researchers that the number of study participants be large. Therefore, we studied two schools, two classes from each school: one class as the control group and the other as the experimental group to ensure that the results of the study would faithfully reflect the investigated population.

\section{Research Instruments}

In this study we used two questionnaires (one tested for motivation and the other for the learning environment), in addition to a pre- and post-test for determining the achievement level.

\section{Motivation instrument}

Glynn et al. (2009), who examined students' motivation to learn science, developed the motivation questionnaire. The questionnaire consists of 26 items, with responses on a five-point Likert scale ranging from 1 (never) to 5 (always). Some examples of item from the questionnaire are: "I use learning strategies that enable effective learning in the sciences"; "I love science as a profession because it challenges me."

The questions were divided into five categories that displayed high reliability using Cronbach's alpha: intrinsic motivation $(\alpha=0.97)$, self-determination $(\alpha=0.94)$, self-efficacy $(\alpha=0.88)$, career motivation $(\alpha=0.76)$, and grade motivation $(\alpha=0.78)$. The questionnaire's overall reliability was 0.97 .

The validity of the questionnaire is predictive and noticeable; thus, the results of the statistical analysis indicate that the instrument differentiates between different groups. In addition, the questionnaire was presented to three people with professional knowledge and interest in this area; all three of them agreed that the instrument addresses and checks the level of motivation among students.

\section{Learning environment instrument}

The learning environment questionnaire was developed by Zedan (2010), in order to test $5^{\text {th }}$ grade students' perception of the classroom environment in mathematics lessons. It was adapted by Hugerat (2016) to test the learning environment among science students. The questionnaire consists of 38 items with responses on a five-point Likert scale, ranging from 1 (not true at all) to 5 (very true). The grade on each scale consists of the mean for the relevant items. Some examples of items from the questionnaire are: "The science class makes me feel restless and restless";" I am satisfied with the science classes I attend."
The items are divided into five categories that describe the level of perception of the social-academic environment in the classroom. They display high reliability using Cronbach's alpha: satisfaction and pleasure $(\alpha=0.93)$, teacher-student relations ( $\alpha=0.95)$, gender tension and inequality $(\alpha=0.72)$, student-student relations $(\alpha=0.91)$, and competitiveness $(\alpha=0.83)$.

\section{Achievement instrument}

The students from the two groups (experimental and control) were also tested for their understanding of digestion; the test is designed to test students' knowledge in the field before and after teaching. Two tests were given to the two groups: (1) a pre-test consisting of three different parts (multiple-choice, open questions, and a table) and (2) a post-test administered at the end of teaching the topic of digestion (experimental and control group); it consisted of four different kinds of questions: (1) multiple-choice, (2) open questions, (3) agreement, and (4) true/false. The pre-test examines the students' basic knowledge before learning about digestion, whereas the post-test, given after teaching the subject, shows the students' achievements. The pre- and post-test were equivalent (having the same difficulty). The pre-test is given to ensure that all the groups are at the same achievement level.

The science teachers of both groups (the experimental and control groups) designed two tests, which were submitted for evaluation to two experts in the fields of science education and educational didactic games.

The pre- and post-tests were developed to fit the curriculum. They underwent two types of validation: Content validation: the contents were validated by (1) three PhDs who were experts in science education, and (2) two experienced grade-school science teachers. The experts received the questionnaire for review and gave their opinions regarding its extent, content, and form. The questionnaire was modified in accordance with their comments. Criterion validation: the questions were created in accordance with the Ministry of Education's formal curriculum for the relevant class.

\section{Semi-structured interview instrument}

The research instrument for the quantitative part consisted of a semi-structured interview based on five questions. One example from the Semi-Structured Interview Instrument follows: "If you chose to become a science teacher in the future, what method would you choose and why?" Ten students were interviewed about their impressions concerning the teaching method they encountered and its contribution to the learning environment and to students' motivation.

Semi-structured in-depth interviews, as opposed to fully structured interviews, enable interviewees to raise additional issues for discussion. This openness helps to generate new insights and provides a complex set of 
Table 1. Effectiveness and correlations among the research variables - the experimental group

\begin{tabular}{|c|c|c|c|c|c|c|c|c|c|c|c|}
\hline & 1 & 2 & 3 & 4 & 5 & 6 & 7 & 8 & 9 & 10 & 11 \\
\hline \multicolumn{12}{|l|}{ Motivation for learning science } \\
\hline Intrinsic motivation & $0.76^{* *}$ & & & & & & & & & & \\
\hline Self-efficacy & $0.49^{* *}$ & $0.33^{*}$ & & & & & & & & & \\
\hline Self-determination & $0.67^{* *}$ & $0.60^{* *}$ & $0.32 *$ & & & & & & & & \\
\hline Career motivation & $0.76^{* *}$ & $0.44^{* *}$ & 0.2 & $0.32^{*}$ & & & & & & & \\
\hline Grade motivation & $0.37^{*}$ & 0.14 & -0.19 & -0.13 & 0.16 & & & & & & \\
\hline Satisfaction and enjoyment & 0.1 & $0.42^{* *}$ & 0.15 & 0.17 & 0.02 & -0.19 & & & & & \\
\hline Student-teacher relationships & 0.27 & $0.35^{*}$ & 0.24 & 0.21 & 0.19 & -0.07 & $0.35^{*}$ & & & & \\
\hline Gender tension and inequality & 0.01 & -0.08 & -0.14 & -0.12 & 0.07 & 0.21 & -0.24 & -0.18 & & & \\
\hline Student-student relationships & 0.03 & 0.08 & 0.2 & 0.15 & 0.04 & -0.24 & 0.13 & $0.46^{* *}$ & -0.20 & & \\
\hline Competitiveness & 0.26 & 0.23 & -0.09 & 0.05 & $0.33^{*}$ & 0.24 & 0.11 & 0.16 & -.19 & $-0.36^{*}$ & \\
\hline Grade: the digestive system & -0.18 & 0.03 & -0.14 & -0.11 & 0.01 & -0.27 & $0.32 *$ & -0.06 & 0.19 & 0.09 & 0.12 \\
\hline
\end{tabular}
${ }^{*} p<0.05,{ }^{* *} p<0.01$

data, parts of which can be used to either support or disprove the research hypotheses. In a semi-structured in-depth interview, a person is interviewed using a series of pre-determined questions; however, their order may change and there may be additional questions as the interview progresses.

\section{Research Procedure}

The study was conducted using the research approach method; it consisted of a pre-test, intervention, a final test (post-test), and data analysis, combined with a quantitative approach (tests, questionnaires) and a qualitative approach (interviews).

\section{Description of the Research Procedure}

Eight classes were chosen from two schools to participate in the study. A 45-minute pre-test on the subject of "easy to digest" was administered. The results were used to divide the sample into two groups: experimental and control. The control group consisted of four classes: the two classes with the highest averages in each school. The experimental group consisted of four classes: the two classes with the lowest averages in each school.

Both groups were given 11 lessons on "easy to digest", a topic in the $5^{\text {th }}$ grade science curriculum (see appendix 1). The lessons for the experimental group included didactic games, whereas the control group learned the same material without the use of didactic games.

Teachers of students in the experimental group taught their students about PBL-JD (Lee et al., 2015; Hadkaew et al., 2008; Takeda et al., 2017). Next, a short frontal lesson was given, followed by a relevant didactic game for each lesson. The students were divided into groups of five students. Each group studied one topic from the digestion project (11 lessons, each lesson on a different topic) using a didactic game. There was a different didactic game in each of the eleven lessons: a dramatic play, computer game, bingo, puzzle, and more (see appendix 1).
Each class of students worked in groups using $P B L-$ $J D$ and performed the didactic game relevant to the chosen science lesson (see appendix 1). The teacher served as a guide and offered guidance only when necessary. Each student in the group had a clear role, and during the didactic game they talk, argue, consult, and help each other to perform the various tasks. At the end of each lesson, after having collected the needed information, every group was asked to present their conclusion. Each group selected a group representative who drew conclusions about the group's work in front of all the groups in the class.

By contrast, the control group continued to learn the subject of "easy to digest" (11 lessons; every lesson is a different topic) using the conventional method, based on frontal teaching, the standard textbook; it is practiced by answering questions, usually simple, which appear at the end of each chapter (more details in appendix 1).

Both groups filled out questionnaires in the classroom; this took about twenty minutes. After the intervention program was carried out and after the questionnaires were filled out, ten students from each group were interviewed. Each semi-structured interview lasted about 20 minutes. Both groups took a final examination that lasted about 45 minutes.

\section{FINDINGS AND DISCUSSION}

First, we describe the research variables and the main connections among them. Tables 1 and 2 present the inner correlations among the variables, separately for the experimental and the control groups.

Table 1 clearly shows that the general "motivation for learning science" index has a significant positive correlation with five of its components: "intrinsic motivation", "self-efficacy", "self-determination", "career motivation", and "grade motivation", with correlation coefficients between $\mathrm{r}=0.37$ and $\mathrm{r}=0.76$. "Intrinsic motivation" also has significant positive correlations with "self-efficacy", "self-determination", "career motivation", as well as with "components of the classroom learning environment", "satisfaction and 
Table 2. Effectiveness and correlations among the research variables - the control group

\begin{tabular}{|c|c|c|c|c|c|c|c|c|c|c|c|}
\hline & 1 & 2 & 3 & 4 & 5 & 6 & 7 & 8 & 9 & 10 & 11 \\
\hline \multicolumn{12}{|l|}{ Motivation for learning science } \\
\hline Intrinsic motivation & $0.97^{* *}$ & & & & & & & & & & \\
\hline Self-efficacy & $0.88^{* *}$ & $0.90^{* *}$ & & & & & & & & & \\
\hline Self-determination & $081^{* *}$ & $0.74^{* *}$ & $0.63^{* *}$ & & & & & & & & \\
\hline Career motivation & $0.90^{* *}$ & $0.88^{* *}$ & $0 / 81^{* *}$ & $0.55^{*}$ & & & & & & & \\
\hline Grade motivation & $0.84^{*}$ & $0.74^{* *}$ & $0.60^{* *}$ & $0.60^{* *}$ & $0 / 71^{* *}$ & & & & & & \\
\hline Satisfaction and enjoyment & $0.73^{* *}$ & $0.74^{* *}$ & $0.66^{* *}$ & $0.78^{* *}$ & $0.58^{\star *}$ & $0.45^{* *}$ & & & & & \\
\hline Student-teacher relationships & $0.88^{* *}$ & $0.89^{* *}$ & $0.73^{* *}$ & $0.74^{* *}$ & $0.82^{* *}$ & $0.68^{* *}$ & $0.81^{* *}$ & & & & \\
\hline Gender tension and inequality & $-0.37^{*}$ & $-0.33^{*}$ & -0.19 & $-0.51^{* *}$ & -0.23 & $-033^{*}$ & $-0.58^{* *}$ & $-0.60 * *$ & & & \\
\hline Student-student relationships & $0.82^{* *}$ & $0.85^{* *}$ & $0.81^{* *}$ & $0.57^{* *}$ & $0.81^{* *}$ & $0.57^{* *}$ & $0.64^{\star *}$ & $0.81^{* *}$ & $-0.31^{*}$ & & \\
\hline Competitive-ness & $0.51^{* *}$ & $0.51^{* *}$ & $0.65^{\star *}$ & $0.56^{* *}$ & $0.34^{* *}$ & 0.23 & $0.63^{* *}$ & $0.38^{* *}$ & -0.13 & $0.33^{*}$ & \\
\hline Grade: the digestive system & 0.16 & 0.18 & 0.15 & 0.15 & 0.1 & 0.12 & $0.33^{*}$ & $0.29 *$ & $-0.35^{*}$ & 0.13 & 0.13 \\
\hline
\end{tabular}
${ }^{*} p<0.05,{ }^{* *} p<0.01$

Table 3. Comparison between the experimental and control group with respect to their grades on the "easy to digest" test

\begin{tabular}{|c|c|c|c|c|c|}
\hline & \multicolumn{2}{|c|}{ Experimental $(n=92)$} & \multicolumn{2}{|c|}{ Control $(n=96)$} & \multirow{2}{*}{$\mathbf{t}$} \\
\hline & $\mathbf{M}$ & SD & $\mathbf{M}$ & SD & \\
\hline Intrinsic motivation & 82.89 & 9.48 & 71.63 & 8.29 & $6.47^{*}$ \\
\hline
\end{tabular}

${ }^{*} p<0.01$

enjoyment", and "student-teacher relations", with correlation coefficients of between $r=0.33$ and $r=0.60$. Interestingly, the topic "student-student relations" correlates positively with "student-teacher relations" $(\mathrm{r}=0.46, \mathrm{p}<0.01)$ and negatively with "competitiveness" $(\mathrm{r}=-0.36, \mathrm{p}<0.05)$.

Table 2 clearly shows that the general "motivation for learning science" index has a significant positive correlation with five of its component scales: "intrinsic motivation", "self-efficacy", "self-determination", "career motivation", and "grade motivation", with correlation coefficients between $\mathrm{r}=0.37$ and $\mathrm{r}=0.76$ as well as with components of the classroom learning environment: "satisfaction and enjoyment" and "student-teacher relationships", "student-student relationships", "gender tension and inequality", and "competitiveness", with correlation coefficients of between $\mathrm{r}=0.37$ and $\mathrm{r}=0.88$.

On the other hand, "grade motivation" has a significant positive correlation with "satisfaction and enjoyment", "student-teacher relationships", and "student-student relationships", with coefficients between $r=0.45$ and $r=0.68$, and a significant negative correlation with "gender tension and inequality" ( $\mathrm{r}=$ $0.33, \mathrm{p}<0.05)$. The category "Satisfaction and enjoyment" also has significant positive correlations with "studentteacher relationships", "student-student relationships", "competitiveness", and "grade on the exam on the digestive system", with coefficients between $r=0.33$ and $\mathrm{r}=0.81$, and a significant negative correlation with "gender tension and inequality $(\mathrm{r}=0.58, \mathrm{p}<0.01)$. The category "Student-teacher relationships" is positively correlated with "student-student relationships", "competitiveness", and "grade on the exam on the digestive system", with coefficients between $r=0.29$ and $\mathrm{r}=0.81$, and it is negatively correlated with "gender tension and inequality" $(r=-0.60, p<0.01)$. "Studentstudent relationships" has a significant negative correlation with "gender tension and inequality" ( $\mathrm{r}=$ $0.31, \mathrm{p}<0.05)$ and a significant positive correlation with "competitiveness" $(\mathrm{r}=0.33, \mathrm{p}<0.05)$. Lastly, "gender tension and inequality" is negatively correlated with "grade on the exam on the digestive system $(r=-0.35$, $\mathrm{p}<0.05)$.

\section{How does the Use of Didactic Games in Teaching Affect Students' Achievements?}

Table 3 shows that the average grade of the control group, which studied by the traditional method, was $71.63(\mathrm{SD}=8.29)$, in contrast to $82.29(\mathrm{SD}=9.48)$ in the experimental group (after the intervention program). The difference in the average grade in favor of the experimental group is statistically significant $(t(186)=6.47, p<0.01)$. In other words, the grades of students who learned science using didactic games were higher than those of students who learned science without games.

It was hypothesized that a significant difference in student achievement would be found between students who learned science using didactic games and those who learned science without them. The findings indicate that students in the experimental group who learned science (the digestive system) using didactic games received better grades than those in the control group, who were taught without the use of didactic games, thus confirming the hypothesis. These findings are consistent with those of Kats (2007), who demonstrated that adding games to teaching results in higher grades in science and mathematics. A possible explanation for this is that the symbolic and concrete representations of scientific concepts and processes expressed through didactic games induce both observation and abstraction of the 
Table 4. Comparison of the experimental and control groups with respect to their motivation to learn science

\begin{tabular}{lccccc}
\hline & \multicolumn{2}{c}{ Experimental $(\mathbf{n = 9 2}$} & \multicolumn{2}{c}{ Control (n=96) } & T \\
\cline { 2 - 5 } & $\mathrm{M}$ & $\mathrm{SD}$ & $\mathrm{M}$ & $\mathrm{SD}$ & $18.03^{*}$ \\
Intrinsic motivation & 4.44 & 0.40 & 2.08 & 0.79 & $18.93^{*}$ \\
Self-efficacy & 4.21 & 0.47 & 2.08 & 0.60 & $14.51^{*}$ \\
Self-determination & 4.34 & 0.60 & 2.12 & 0.84 & $12.18^{*}$ \\
Career motivation & 4.27 & 0.75 & 2.13 & 0.81 & $12.87^{*}$ \\
Grade motivation & 4.27 & 0.59 & 2.37 & 0.81 & $18.82^{*}$ \\
Overall motivation & 4.31 & 0.34 & 2.16 & 0.69 & \\
\hline
\end{tabular}

${ }^{*} p<0.01$

learned concepts (Martin \& Dawson, 2009). The use of concrete games improves the acquisition procedure for conceptual knowledge in a variety of scientific topics and may help improve academic achievement (Chao et al., 2000). Games, as part of teaching, provide students with a meaningful visual experience and nonjudgmental feedback (Ben-Menahem, 2005).

This result received further support from students' responses in interviews, such as: "Learning through games influenced me greatly. I knew how to solve problems in the test"; "Learning through games improved my memory"; "Yes, I received a very good grade in science, the highest grade on my report card, thanks to having learned through games".

Our finding is in line with the findings of Selvi \& Çosan (2018), who found that educational games enhance students' achievement and are an effective tool for providing the retention of new knowledge. Within the scope of the study, the experimental group students' views on the use of educational games were obtained at the end of the implementation, and they were generally positive. The students found the games informative, entertaining, and that they reinforced their learning, and stated that they are effective in enabling the retention of new knowledge, promoting collaboration with their peers, and increasing their interest and motivation for learning.

\section{How does Using Didactic Games in Teaching Affect the Motivation to Study Science?}

Table 4 shows that the overall motivation to learn science is significantly higher among the students in the experimental group $(t(186)=18.82, p<0.01)$. In addition, significant differences $(p<0.01)$ were found between the two groups with respect to "intrinsic motivation", "selfefficacy", "self-determination", "career motivation", and "grade motivation". In all five of these indices the students in the experimental group exhibited greater motivation

It was hypothesized that there would be differences in motivation between students who learned science using games and those who did not. The findings indeed point to a significant difference in the levels of motivation, enjoyment, and interest among students who learned science using the two different methods. The students in the experimental group exhibited higher levels of motivation, enjoyment, and interest than their peers in the control group. A clear, significant rise in all categories, associated with motivation to learn this topic and also with the overall motivation, was found among students who learned science using games.

Introducing games into teaching and learning contributes to promoting motivation, enjoyment, and interest among children as well as teachers. Learning through games is efficient because it allows the material to be learned naturally and the teaching goals to be attained indirectly (Tal, 1993). It enhances motivation and can make students more willing to invest effort in their studies. It is therefore important for teachers to encourage students' motivation, preserve the preliminary motivation, and continue to direct it, because engaging in games is an experience that challenges and assists students over time. Students' motivation was increased because learning through games is a motivating force that induces one to invest physical, mental, and psychological effort in work and other activities, willingly and with no coercion.

Similar findings were also derived from the interviews held with some of the students in the experimental group, when they were asked about their opinions regarding learning through games: "The subject of science has become more attractive and interesting". Students' responses concerning their motivation to learn science following the use of games are also included in this category, for example: "The effect was positive, when learning is fun, motivation always improves". "I loved the games, which helped me very much to understand subjects that I had difficulty in understanding"; "The method of using didactic games in science made topics easier". "I now feel that I know the study material"; "It had a positive effect on me and I obtained a good understanding of the food groups and it motivated me to learn more"; "The method of using didactic games is good because through games we understand more".

Students' responses concerning their interest in science are also included in this category: "Yes, I love science more, and want to become a science teacher". Christina (a pseudonym) said: "Science has become a more attractive and interesting subject" and Amal (a pseudonym) stated: "I would choose a method that 
Table 5. Comparison of the experimental and control groups with respect to the learning environment

\begin{tabular}{lccccc}
\hline & \multicolumn{2}{c}{ Experimental $(\mathbf{n}=\mathbf{9 2})$} & \multicolumn{2}{c}{ Control (n=96) } & T \\
\cline { 2 - 5 } & $\mathbf{M}$ & SD & $\mathbf{M}$ & $\mathbf{S D}$ & $17.37^{*}$ \\
Satisfaction and enjoyment & 4.35 & 0.31 & 2.27 & 0.75 & $16.85^{*}$ \\
Student-teacher relationships & 4.38 & 0.35 & 2.35 & 0.74 & $-9.53^{*}$ \\
Gender tension and inequality & 1.56 & 0.67 & 2.73 & 0.51 & $19.90^{*}$ \\
Student-student relationships & 4.03 & 0.38 & 2.04 & 0.56 & $11.34^{*}$ \\
Competitiveness & 3.90 & 0.66 & 2.19 & 0.78 & \\
\hline
\end{tabular}

${ }^{*} p<0.01$

includes didactic games, because in this method all the students participate, even the weak ones".

\section{How does Using Didactic Games in Teaching Affect the Learning Environment?}

Table 5 shows the level of significance of the five categories, as well as the means and standard deviations of the experimental and control groups with respect to the learning environment.

It was hypothesized that there would be differences between students who learned science using games and those who did not, regarding their attitude toward the learning environment in the classroom, and that those who learned games would report having had a better learning environment.

As shown in Table 5, a significant difference was found in students' attitudes: Students in the experimental group reported having a more positive attitude toward their learning environment than did those in the control group, thus fully confirming this hypothesis with respect to all five components of the learning environment:

Satisfaction and enjoyment: The data show that among students in the experimental group, the mean level of satisfaction $(\mathrm{M}=4.35, \mathrm{SD}=0.31)$ was higher than that in the control group $(\mathrm{M}=2.27, \mathrm{SD}=0.75)$. Thus, the experimental group reported a higher degree of satisfaction regarding the situation in the classroom and the way that the science lessons were taught.

Student-teacher relationship: The data show that students in the experimental group perceived the student-teacher relationship more positively than did students in the control group $(\mathrm{M}=4.38, \mathrm{SD}=0.35$ in the experimental group, versus $\mathrm{M}=2.35, \mathrm{SD}=0.74$ in the control group).

This finding shows that a positive, supportive, and warm relationship existed between the teacher and the students, at the personal as well as the academic level. It reflects a clear and strict maintenance of academic norms, which results in student success. It also shows that teachers who use didactic games in science lessons provide clearer instructions and impose better discipline and clearer rules and regulations than do teachers who do not use games in their science lessons. Students who learned didactic games are thus more aware of the rules and the consequences of violating them.
Gender tension and inequality: The level of gender tension and inequality was found to be lower in the experimental $(M=1.56, S D=0.67)$ than in the control group $(M=2.73, S D=0.51)$. This result indicates that teachers treat boys and girls equally and it disproves the claim that boys receive preferential treatment. The findings show that in science lessons in which the teacher uses didactic games the gender tension and inequality are less than in lessons in which the teacher does not use didactic games.

Student-student relationships: The data show that among students in the experimental group that learned science with the help of games the student-student relationships were better $(\mathrm{M}=4.03, \mathrm{SD}=0.38)$ than among students in the control group $(\mathrm{M}=2.04, \mathrm{SD}=0.56)$. Thus, it can be concluded that adding didactic games to a science lesson results in a more cohesive class and a better relationship among students.

Competitiveness: The data show a higher level of competitiveness in the experimental group $(\mathrm{M}=3.90$, $\mathrm{SD}=0.38)$ than in the control group $(\mathrm{M}=2.19, \mathrm{SD}=0.78)$. Students in the experimental group strove toward greater achievement and insisted on carrying out classroom tasks with greater precision than did their peers in the control group, where the desire to succeed was lower and students did not compete for the teacher's attention in science lessons.

To summarize, Table 5 shows that students in the experimental group reported a significantly better learning environment $(p=0.01)$ than did students in the control group regarding the components "satisfaction and enjoyment", "student-teacher relationships", "student-student relationships", and "competitiveness", whereas students in the control group reported a higher level of "gender tension and inequality" in their classroom.

According to Wassermann (1992), a child realizes that his loss in a game stems from a mistake that can be rectified in the next game, because there are no standards of "right" and "wrong" in a game. Children must be made to feel that they are playing freely during the game in the science lesson, and that they are not pressured by a time limit.

These findings are in agreement with the notion that a teaching approach that includes the use of games promotes independence and high motivation to learn, together with a positive learning environment (Allery, 
2014; Patel, 2008). Students' positive feelings are also promoted by their feelings of enjoying what they are doing; therefore, it is recommended that the learning experience will provide the same kind of enjoyment that student's experience when they play outside the classroom (Klopfer, Osterweil, \& Salen, 2009; Su, Cheng, \& Lin, 2014; Santini et al., 2018).

The same findings are also reflected in students' positive attitudes toward the sciences in their interviews: "There was a positive effect. I loved the subject"; "Including the games was interesting and made me understand the subject better, because I love to play"; "I loved the method, which included didactic games, because it influences the students"; "I became more interested in studying science and the method of including didactic games brought the subject closer to me"; "Yes, there is an improvement. I love science, which is an interesting and challenging subject". Yusuf (a pseudonym) gave an interesting answer: "Through the games there is always competition between the groups and we have to think carefully before giving an answer, so that we don't lose. That way we learn from each other"; another response was from Fatima (a pseudonym): "The method of including games is more enjoyable. We laugh more. It's fun and less stressful"; and Amira (a pseudonym) expressed a sense of emotional relief: "This method of study made it psychologically easier for me. I feel more comfortable because I understood the subject better". Amal (a pseudonym) said: "I would choose a method that included didactic games, because with it all the students participate, even the weak ones".

It was concluded that the intervention program in which students in the experimental group learned about digestion via educational didactic games using the $P B L$ $J D$ method brought about an improvement in their motivation to learn science, and an improvement in their perception of the classroom climate. In addition, $P B L-J D$ improves students' motivation and their perception of the classroom climate more in urban areas than in rural areas. The students' answers indicate that their verbal positions are consistent with the findings of the quantitative questionnaires, and this strengthens their validity.

\section{CONCLUSION}

This study showed that didactic games provide a way for enjoyable learning, development of curiosity and imagination, as well as development of social skills and abilities. This study focused on the correlation between teaching by using didactic games in science and the motivation for learning as well as ways to enhance the learning environment among primary school students.

It was found that including didactic games in teaching improved students' grades on the topic of "easy to digest" (science), improved student motivation in all of the six components examined, and improved the classroom learning environment in all of the five components examined: A positive effect was found in the categories "satisfaction and enjoyment", "studentteacher relationships", "student-student relationships", and "competitiveness", whereas a negative effect was found in "gender tension and inequality".

Because the research findings indicate that didactic games improve students' achievement and motivation to learn and also positively impact the learning environment, principals and teachers who are interested in improving students' motivation, learning, and achievement in a creative and interesting way should consider using didactic games.

\section{Declaration of Ethical Standards and Issues}

The research described here was conducted among $5^{\text {th }}$ grade students studying science. We asked the students for their consent to participate in the study, which included both recording their discussions (ingroup) as well as conducting interviews. We promised the students to use the information for research purposes only and not for assessing them in terms of their knowledge and attitudes. The results were not used for grading purposes.

After completing the study, the students in the control group that studied the subject using the conventional method again learned a large part of the subject using the didactic game method.

\section{REFERENCES}

Afari, E., Aldridge, J. M., Fraser, B. J., \& Khine, M. S. (2013). Students' perceptions of the learning environment and attitudes in game-based mathematics classrooms. Learning Environments Research, 16(1), 131-150. https://doi.org/10.1007/ s10984-012-9122-6

Allery, L. (2014). Make use of educational games. Education for Primary Care, 25(1), 65-66. https:/ / doi.org/10.1080/14739879.2014.11494245

Ames, C. (1992). Achievement goals, motivational climate, and motivational processes. In G. C. Roberts (Ed.), Motivation in Sport and Exercise (pp. 161-176). Human Kinetics.

Arbel, H., Lahman, D., Aofestien, N., Kawfman, H., \& Keblentsky-Bendor, D. (2011). Lemeda bemtsaut meshakeem [Learning through games]. Oorika, 32, 1-14 (Hebrew).

Bailey, S., \& Watson, R. (1998). Establishing basic ecological understanding in younger pupils: a pilot evaluation of a strategy based on drama/role play. International Journal of Science Education, 20(2), 139152. https:/ / doi.org/10.1080/0950069980200202

Bassuk, S., Church, T., \& Manson, J. (2013). Researchers explain why exercise works magic. Scientific 
American, 309(2), 74-79. https://doi.org/10.1038/ scientificamerican0813-74

Begoray, D. L., \& Stinner, A. (2005). Representing science through historical Drama. Science $\mathcal{E}$ Education, 14(3-5), 457-471. https://doi.org/ $10.1007 / \mathrm{s} 11191-005-0780-y$

Ben-Menahem, E. (2005). Meshak owmtseuot - hatsad haregshee shel horaat hamadaim. [Game and Reality - The Emotional Side of Teaching Science]. Oorika, 28, 1-14 (Hebrew).

Beswick, K. (2011). Putting context in context: An examination of the evidence for the benefits of 'contextualised' tasks. International journal of science and mathematics education, 9(2), 367-390. https: / / doi.org/10.1007/s10763-010-9270-z

Chang, C. C. (2009). Using jigsaw collaborative learning strategy in online discussion to foster a project based learning community on the Web. International Journal of Instructional Media, 36(2), 221233.

Choe, S. W. T., \& Drennan, P. M. (2001). Analyzing scientific literature using a jigsaw group activity: Piecing together student discussions on environmental research. Journal of College Science Teaching, 30(5), 328-330.

Chao, S., Stigler, J. W., \& Woodward, A. J. (2000). The effects of physical materials on kindergartners' learning of number concepts. Cognition and Instruction, 18(3), 285-316. https://doi.org/ 10.1207/S1532690XCI1803_1

da Silva Júnior, J. N., Sousa Lima, M. A., Nunes Miranda, F., Melo Leite Junior, A. J., Alexandre, F. S. O., de Oliveira Assis, D. C., \& Nobre, D. J. (2018). Nomenclature bets: An innovative computer-based game to aid students in the study of nomenclature of organic compounds. Journal of Chemical Education, 95(11), 2055-2058. https://doi.org/ 10.1021/acs.jchemed.8b00298

Foster, A. (2008). Games and motivation to learn science: personal identity, applicability, relevance and meaningfulness. Journal of Interactive Learning research, 19(4), 597-614.

Fraser, B. J., \& Walberg, H. J. (Eds.) (1991). Educational Environments: Evaluation, Antecedents, Conseqences. Pergamon.

Glynn, S. M., Taasoobshirazi, G., \& Brickman, P. (2009). Science motivation questionnaire: Construct validation with nonscience majors. Journal of Research in Science Teaching, 46(2), 127-146. https:/ / doi.org/10.1002/tea.20267

Goleman, D. (2006). Social intelligence: then new science of human relationships. Bantam Dell.

Hadkaew, P., Wiwatanapataphee, B., \& Wu, Y. H. (2008). Project-based learning model for the study of blood flow in the human blood circulatory system. International Journal of Learning, 15(3), 195-202. https:/ / doi.org/10.18848/1447-9494/CGP/ v15i03/45686

Hannula, M., \& Lehtinen, E. (2005). Spontaneous focusing on numerosity and mathematical skills of young children. Learning and Instruction, 15(3), 237256. https://doi.org/10.1016/j.learninstruc.2005. 04.005

Hartley, R. E., Frank, L. K., \& Goldenson, R. (2013). Understanding children's play. Routledge.

Hugerat, M. (2016). How teaching science using projectbased learning strategies affects the classroom learning environment. Learning Environments Research, 19(3), 383-395. https://doi.org/10.1007/ s10984-016-9212-y

Jancic, P., \& Hus, V. (2018). Teaching social studies with games. International Journal of Game-Based Learning, 8(2), 68-79. https://doi.org/10.4018/IJGBL. 2018040106

Karbach, J., \& Schubert, T. (2013). Training-induced cognitive and neural plasticity. Frontiers in human neuroscience, 7, 48. https://doi.org/10.1007/ s10984-012-9122-6

Kats, V. J. (2007). Algebra, getaway to a technological future. Mathematical Association of America.

Klopfer, E., Osterweil, S., \& Salen, K. (2009). Moving learning games forward. The Education Arcade.

Krasnor, L. R., \& Pepler, D. J. (1980). The study of children's play: Some suggested future directions. In K. H. Rubin (Ed.), Children's play: New directions for child development (pp. 85-95). Jossey-Bass. https://doi.org/10.1002/cd.23219800908

Lee, S., Kang, E., \& Kim, H. B. (2015). Exploring the impact of students' learning approach on collaborative group modeling of blood circulation. Journal of Science Education and Technology, 24(2-3), 234-255. https://doi.org/10.1007/s10956-0149509-5

Leisman, G., Machado, C., \& Mualem, R. (2013).) The merging the neurosciences principles with educational practice in the treatment of ADHD: Function specific treatment for rehabilitation. Frontiers of Public Health: Frontiers of Child Health and Human Development, 1, 22. https://doi.org/ 10.3389/fpubh.2013.00022

Liu, E. Z. F., \& Chen, P. K. (2013). The effect of gamebased learning on students' learning performance in science learning - A case of "Conveyance Go". Procedia-Social and Behavioral Sciences, 103, 10441051. https:/ / doi.org/10.1016/j.sbspro.2013.10.430

Martin, A. J., \& Dowson, M. (2009). Interpersonal relationships, motivation, engagement, and achievement: Yields for theory, current issues, and 
educational practice. Review of Educational Research, 79(1), 327-365. https://doi.org/10.3102/ 0034654308325583

Mayo, M. J. (2010). Bringing game-based learning to scale: the business challenges of serious games. International Journal of Learning \& Media, 2(2-3), 81100. https:/ / doi.10.1162/ijlm_a_00048

McCaslin, M., \& Good, T. L. (1996). The informal curriculum. In D. C. Berliner, \& R. C. Calfee (Eds.), Handbook of educational psychology (pp. 622-670). Simon \& Schuster Macmillan.

McNeil, N., \& Jarvin, L. (2007). When theories don't add up: Disentangling $\mathrm{B}$ the manipulatives debate. Theory and Practice, 46(4), 309-316. https:/ / doi.org/10.1080/00405840701593899

Meece, J. L., Blumenfeld, P. C., \& Hoyle, R. H. (1988). Students goal orientations and cognitiv engagement in classroom activities. Journal of Educational Psychology, 80(4), 514-523. https:// doi.org/10.1037/0022-0663.80.4.514

Moreno, L. F., Hincapié, G., \& Alzate, M. V. (2014). Cheminoes: A didactic game to learn chemical relationships between valence, atomic number, and symbol. Journal of Chemical Education, 91(6), 872-875. https://doi.org/10.1021/ed4008183

Patel, J. (2008). Using game format in small group classes for pharmacotherapeutics case studies. American Journal of Pharmaceutical Education, 72(1), 21. https://doi.org/10.5688/aj720121

Pintrich, P. R., \& Schunk, D. H. (2002). Motivation in education: Theory, research, and applications $\left(2^{\text {nd }} E d\right.$.). Prentice Hall.

Randler, C. \& Bogner, F. X. (2009). Efficacy of Two Different Instructional Methods Involving Complex Ecological Content. International Journal of Science and Mathematics Education, 7(2), 315-337. https:/ / doi.org/10.1007/s10763-007-9117-4

Sánchez-Rivas, E., Ruiz-Palmero, J., \& SánchezRodríguez, J. (2019). Gamification of assessments in the natural sciences subject in primary education. Educational Sciences: Theory and Practice, 19(1), 95111.

Santini, J. T., Bloor, T., \& Sensevy, G. (2018). Modeling Conceptualization and Investigating Teaching Effectiveness. Science \& Education, 27(9-10), 921-961. https:// doi.org/10.1007/s11191-018-0016-6

Saputra, M. D., Joyoatmojo, S., Wardani, D. K., \& Sangka, K. B. (2019). Developing critical-thinking skills through the collaboration of jigsaw model with problem-based learning model. International Journal of Instruction, 12(1), 1077-1094. https://doi.org/ $10.29333 /$ iji.2019.12169a
Schiller, P. (2010). Early brain development research review and update. Brain Development, 196, 26-30.

Shonkoff, J. P., \& Levitt P. (2010). Neuroscience and the future of early childhood policy: Moving from why to what and how. Neuron, 67(6), 689-691. https:// doi.org/10.1016/j.neuron.2010.08.032

Selvi, M., \& Çosan, A. Ö. (2018). The effect of using educational games in teaching kingdoms of living things. Universal Journal of Educational Research, 6(9), 2019-2028. https://doi.org/10.13189/ujer.2018. 060921

Siraj-Blatchford, I., \& Kwi-Ok, N. (2014). A comparison of the pedagogical practices of mathematics education for young children in England and South Korea. International Journal of Science and Mathematics Education, 12(1), 145-165. https:/ / doi.org/10.1007/s10763-013-9412-1

Sousa Lima, M. A., Monterio, A. C., Melo Leite Junior, A. J. M., de Andrade Matos, I. S., Alexandre, F. S. O., Nobre, D. J., Monteiro, A. J., \& da Silva Júnior, J. N. (2019). Game-based application for helping students review chemical nomenclature in a fun way. Journal of Chemical Education, 96(4), 801-805. https:// doi.org/10.1021/acs.jchemed.8b00540

$\mathrm{Su}, \mathrm{T} .$, Cheng, M. T., \& Lin, S. H. (2014). Investigating the effectiveness of an educational card game for learning how human immunology is regulated. CBE-Life Sciences Education, 13(3), 504-515. https:/ / doi.org/10.1187/cbe.13-10-0197

Tal, M. (1993). Shelov h'meshak betahlechee lmeda lama o'ketsad? [Integrating the game into learning processes - why and how]. Levensky College, H'amerkaz laheshtalmoiut ovdee horah o'mesrad henoch, $\mathrm{H}^{\prime}$ merkazeem H'bedagogeem (Hebrew).

Takeda, K., Takahashi, K., Masukawa, H., \& Shimamori, Y. (2017). Influence on learning of a collaborative learning method comprising the jigsaw method and problem-based learning (PBL). Yakugaku zasshi: Journal of the Pharmaceutical Society of Japan, 137(6), 659-664. https://doi.org/10.1248/yakushi.1600224-2

Triboni, E., \& Weber, G. (2018). MOL: Developing a European-style board game to teach organic chemistry. Journal of Chemical Education, 95(5), 791803. https:// doi.org/10.1021/acs.jchemed.7b00408

Wassermann, S. (1992). Serious play in the classroom. Childhood Education, 68(3), 133-139. https:// doi.org/10.1080/00094056.1992.10522562

Zedan, R. (2010). New dimensions in the classroom climate. Learning Environments Research, 13(1), 7588. https:/ / doi.10.1007/s10984-009-9068-5 


\section{APPENDIX 1}

The lessons in the experimental group were taught using PBL-JD. The students were divided into groups in each lesson (11 lessons); they learned the subject according to educational didactic games. The control group learned the same topics; the students were divided into groups; they learned the material from the book using the frontal method and solved the questions at the end of each chapter.

\section{Details about the Lessons in Both Groups}

Experimental group- A short frontal lesson, followed by a relevant didactic game for each lesson, as follows:

Drinking and water (Lesson 1): A dramatic game: a story about a man who lived in the desert.

The water in our body (Lesson 2): A board game: A race to health.

The role of water in our body (Lesson 3): A computer game: A puzzle.

Drinking water for our health (Lesson 4): Ladders and snakes.

Why do we have to eat? (Lesson 5): The wheel of fortune.

The main food groups (Lessons 6 and 7): Bingo; the class is divided into five groups. A lottery game: Essential nutrients.

Healthy nutritional habits (Lessons 8 and 9): A dramatic game about two restaurants, followed by answering questions about what the students had eaten in the past three days. Who wants to be a millionaire?

Processed food (Lesson 10): The game of luck: The class is divided into two groups, representing natural and processed foods. Every student chooses a card with a picture of a food. Every student whose card fits his group receives a point.

Summary (Lesson 11): Solving a worksheet and completing the motivation questionnaire.

Control group- Frontal lessons with intensive use of the textbook; no games.

Drinking and water (Lesson 1): Reading the opening poem, which informs the students that the subject matter is drinking as well as water in the desert.

The water in our body (Lesson 2): Reading an informative passage and answering questions from the textbook: Where is there water in our body?

The role of water in our body (Lesson 3): Reading an informative passage and answering questions from the textbook: The qualities that make water important for life.

Drinking water for our health (Lesson 4): An informative passage and questions: Maintaining the proper quantity of water in our body + a search task to be carried out at home.

Why do we have to eat? (Lesson 5): Reading an informative passage from the textbook; a worksheet handout and reading a poem.

The main food groups (Lessons 6 and 7): Frontal teaching, using illustrations; answering questions from the textbook. Constructing a food pyramid. An independent task: the kinds of food at home, a presentation in class during the next lesson, the teacher's summary using tables.

Healthy nutritional habits (Lessons 8 and 9): Performing two tasks from the textbook. Students are asked to monitor and document their eating habits for three days.

Processed food (Lesson 10): Preliminary activity: What meaning do students give to the concepts "natural" and "processed" food? Reading a passage about natural and processed food and answering the questions.

Summary (Lesson 11): Solving a worksheet and completing the motivation questionnaire.

\section{http://www.ejmste.com}

